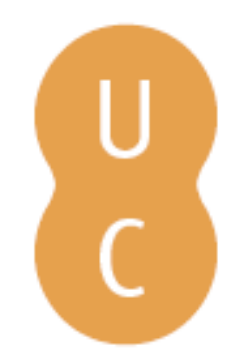

\title{
pommalina
}

\section{Temporal orientation and future time perspective of adolescents in institutional care}

\author{
Autor(es): Lima, Luiza Nobre
}

Publicado por: Imprensa da Universidade de Coimbra

URL

persistente: $\quad$ URI:http://hdl.handle.net/10316.2/38608

DOI: $\quad$ DOI:http://dx.doi.org/10.14195/978-989-26-0775-7_4

Accessed : $\quad$ 26-Apr-2023 15:46:45

A navegação consulta e descarregamento dos títulos inseridos nas Bibliotecas Digitais UC Digitalis, UC Pombalina e UC Impactum, pressupõem a aceitação plena e sem reservas dos Termos e Condições de Uso destas Bibliotecas Digitais, disponíveis em https://digitalis.uc.pt/pt-pt/termos.

Conforme exposto nos referidos Termos e Condições de Uso, o descarregamento de títulos de acesso restrito requer uma licença válida de autorização devendo o utilizador aceder ao(s) documento(s) a partir de um endereço de IP da instituição detentora da supramencionada licença.

Ao utilizador é apenas permitido o descarregamento para uso pessoal, pelo que o emprego do(s) título(s) descarregado(s) para outro fim, designadamente comercial, carece de autorização do respetivo autor ou editor da obra.

Na medida em que todas as obras da UC Digitalis se encontram protegidas pelo Código do Direito de Autor e Direitos Conexos e demais legislação aplicável, toda a cópia, parcial ou total, deste documento, nos casos em que é legalmente admitida, deverá conter ou fazer-se acompanhar por este aviso. 


\section{INTERNATIONAL \\ STUDIES IN TIME \\ PERSPECTIVE}

MARIA PAULA PAIXÃO

JOSÉ TOMÁS DA SILVA

(COORD.)

VICTOR ORTUÑO

PEDRO CORDEIRO

(EDITORS)

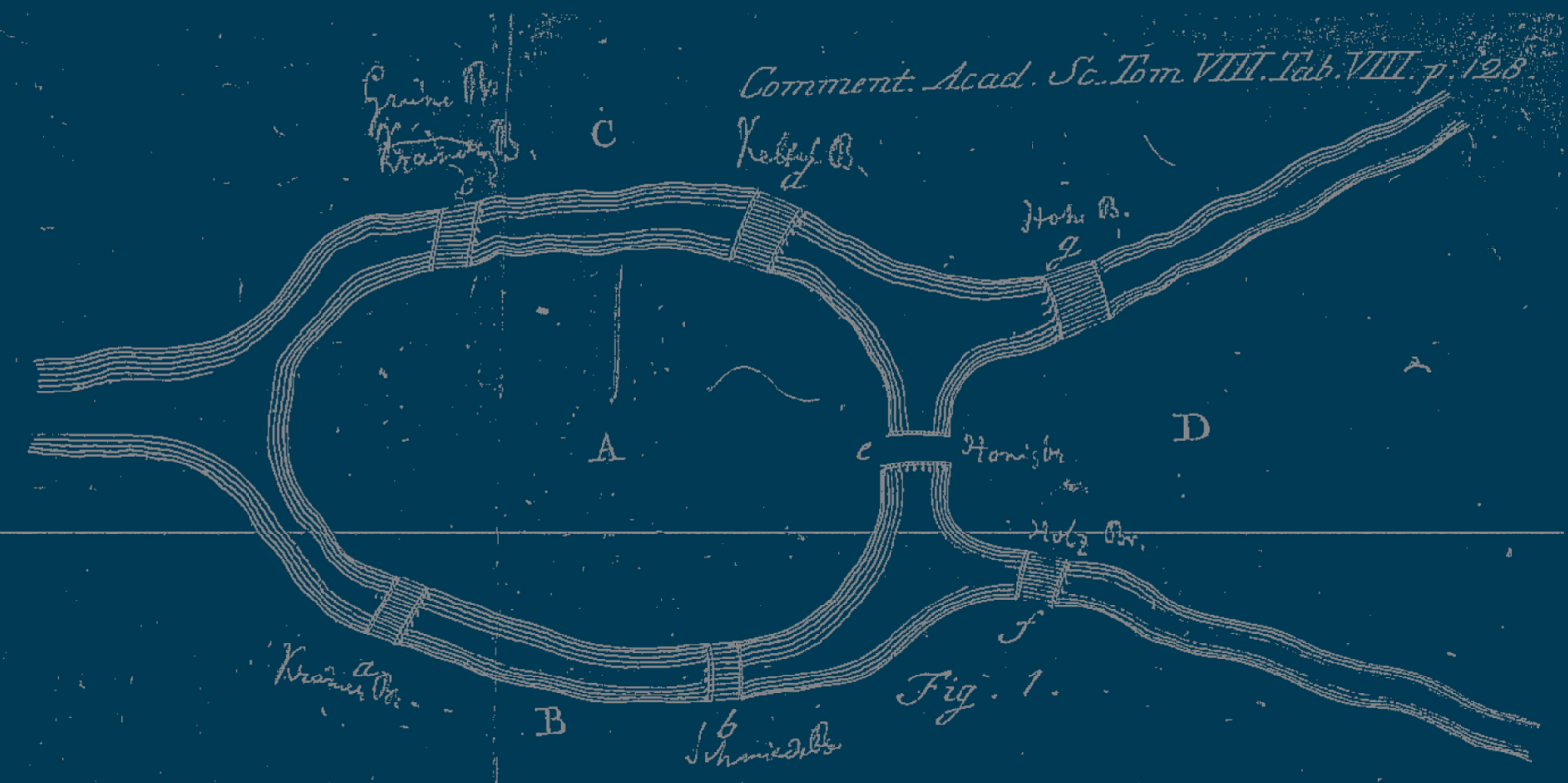

IMPRENSA DA

UNIVERSIDADE

DE COIMBRA

COIMBRA

UNIVERSITY

PRESS 


\title{
Chapter 4 \\ Temporal Orientation and Future Time Perspective of Adolescents in InSTITUTIONAL CARE
}

\author{
Luiza Nobre Lima \\ Faculty of Psychology and Educational Science, University of Coimbra, Portugal \\ luizabelima@fpce.uc.pt
}

\begin{abstract}
Aвstract: Based on the paradigm of Dan McAdams, according to which identity is constructed in narrative, an exploratory research of qualitative nature was conducted on the life stories and the projects for the future of adolescents placed in Childhood and Youth Homes, under the protection measure of extended placement in an institution. This study sought to answer, among others, the following research questions: Are the institutionalized adolescents more oriented towards the past than towards the future? What projects do the adolescents make for their future lives? Following the methodology of Grounded Analysis, 17 adolescents, between the ages of 15 and 18, with a minimum of 5 years of institutionalization, were interviewed. The results showed that: 1) there are no significant statistical differences between the orientation towards the past, present and future of these institutionalized adolescents; 2) their future time perspective is sparse, poorly structured, more imagined than motivational, and is mainly composed of the objects which can ensure them the basic conditions for subsistence, such as having a job and a home. From the findings obtained during this research some practical implications were taken, which concern some aspects of the care provided to the institutionalized children and adolescents.
\end{abstract}

Keywords: adolescents, institutionalization, temporal orientation, future time perspective.

\section{INTRODUCTION}

One of the main inspirers behind the concept of future time perspective, understood as the image that an individual has of his future, was Nuttin (1963 in Abreu, 1999). Particularly interested in the motivational force that the time perspective plays in behaviour, Nuttin focused on the component of future time perspective, which he widely studied. After Nuttin, future time perspective was developed by other authors like Gisela Trommsdorff and Rachel Seginer that boosted research in this field. In examining the concept of future time perspective, Trommsdorff (Trommsdorff \& Lamm, 1975; Lamm, Schmidt \& Trommsdorff, 1976) ended up replacing it by the concept of future orientation, and this replacement came to be accepted and used by the researchers that followed her, in particular by Seginer or Nurmi. However, this substitution of concepts seems to conflict with other dimensions of psychological time, which may result in some kind of conceptual confusion. 
When Nuttin and Lens (1985) presented the definition of future time perspective, they carefully clarified the ambiguity that the more general concept of time perspective contained. "A clear distinction has to be made between three different aspects of psychological time which often are referred to by the same term "time perspective». The first is time perspective proper, which is essentially characterized by its extension, density, degree of structuration, and level of realism (...). The second is time attitude and refers to a subject's more or less positive or negative attitude towards the past, the present, and the future. (...) Time orientation, finally, refers to the preferential direction in a subject's behaviour and thought insofar as it is predominantly oriented towards objects and events in the past, the present, and the future" (p. 11).

When making this distinction, especially between temporal perspective and temporal orientation, Nuttin and Lens (1985) sought to make clear that they understood by time perspective all the objects located in a time more or less extended and that are virtually present to the subject in connection with his behaviour. The virtual object becomes actually present when it is aroused by a circumstance or an important motivation, making it part of the behavioural world of the subject in the sense that it is a kind of a goal to be achieved. "In general, the objects of time perspective are among the determinants that regulate behaviour" (p. 22).

Despite the distinction made by these authors and their investment in the study of the future dimension of time perspective, an indiscriminate use of the concepts of future time perspective and future orientation has been made, both used in some literature to mean the same. An example of this conceptual confusion arises with some authors (Zimbardo $\&$ Boyd, 1999) using the concept of time perspective to assess what they consider to be a cognitive orientation of personal and social experiences for a given temporal zone (past, present or future).

Assuming the distinction of Nuttin and Lens (1985) between temporal orientation and time perspective, a few remarks should follow to clarify temporal orientation concept.

\section{Temporal orientation}

Temporal orientation is mostly related to the degree of involvement of an individual, at a given moment of his life, with the different temporal zones. That is, the individual will be more oriented to the past, to the present or to the future, depending on the objects and events he is more focused and their placement on one of these temporal zones. This involvement can be both at the level of thought or at the level of action, although for practical reasons research on temporal orientation takes into account the level of thought. Implicitly, it is considered that there is a simple connection between thought and action (De Volder, 1979).

For people oriented to the past, the self-concept and self-assessment are based on what has happened in the past. In turn, people oriented to the present tend not to consider the past in their present life, nor to bother themselves with the future consequences of their behaviour. As for people who are more oriented to the future, they are defined by what they expect and wish for their future (Lens, 2006).

Studies on temporal orientation reveal that a predominant attention in the past (and sometimes in the future) may have negative consequences for identity formation (Rappaport, Enrich \& Wilson, 1985) and to satisfaction with the self (Braley \& Freed, 
1971). Orientation to the past also seems to be associated with the experience of traumatic events (Lomranz et al, 1985; Holman \& Silver, 1998). The life narratives of depressed individuals show that they are more immersed in the past (Habermas et al, 2007), as well as life narratives of child abuse survivors are more focused in the past and devalue the central role of the self (Klein \& Janoff-Bulman, 1996).

Several studies have found that children and teenagers raised in risk environments but who have positive expectations regarding their future and make plans for it, are less likely to experience psychological and social problems later in life. For example, Wyman and colleagues (1992) have found positive expectations regarding the future to differentiate resilient children from non-resilient children exposed to high levels of stress. Quinton, Pickles, Maughan and Rutter (1993), in a sample of institutionalized children, found that during adolescence future planning was predictor of less behavioural problems and also of the choice of partners with fewer conduct problems in adulthood.

\section{Future Time Perspective}

According to Nuttin and Lens (1985), future time perspective is a concept operationalized in the following components: 1) its extension, or length or depth, 2) the density with which the objects are distributed on the future, 3) the degree of structure between those scattered objects, i.e., the presence or absence of links between objects or groups of objects, and 4) the degree of realism with which objects are perceived by the subject as a function of their distance in time. Thus, the future time perspective is a variable with a motivational value in behaviour, able to mediate the action of the individual to achieve the objects placed on the future.

Trommsdorff (1986) replaced the concept of future time perspective by future orientation which, although close to the concept used by Nuttin, is a little wider because it also includes a motivational and emotional component. This author actually justifies this conceptual change by integrating this component, making future orientation a multidimensional construct that, in addition to the dimensions of density (number of events which occurrence one expects or fears in several life domains) and extension (operationalized as the event that the subject places further in the future), has an affective dimension (optimism/pessimism). A final dimension is the internal-external control, which defines the belief that the individual has about who controls the events, that is, himself or external forces.

Seginer (1988) and Nurmi (1991) developed and further extended the concept of future orientation (that should be understood as if it were future time perspective of Nuttin [1963, in Abreu, 1999]). Nurmi (1991) considered that the way adolescents see their future should be described in terms of three key processes: motivation, planning and evaluation. In his view, first the teenager sets goals based on the comparison between his motives and values and his expectations for the future. Then, he seeks to plan strategies that will allow him to achieve the goals and, finally, evaluates the possibility of achieving these goals and update the plans he draw. In this evaluation, causal attributions and the affect towards the future play an important role.

Future orientation thus reflects the subjective representation that the individual has of his own future. Because of the developmental characteristics of adolescence many studies 
have been conducted on the future orientation of adolescents. When asked about their desires and fears, many adolescents show concern about their future (Nurmi, 1991). In many cultures the goals that adolescents most anticipate respect to their future education, their profession, family life and leisure activities (Poole \& Cooney, 1987; Nurmi, Poole \& Seginer, 1995). To a lesser extent, still appear in the future goals of adolescents references to other domains such as migration, housing or military service, the latter more reported by boys (Malmberg \& Norrgard, 1999). Crisis situations are considered as part of the normative life course, but poorly integrated in the future of the adolescents themselves. "Crises are more likely to happen to most other people than to themselves" (Malmberg \& Norrgard, 1999, 43). Regarding worries and fears concerning their future, adolescents tend to mention the threat of war, pollution and social development (Malmberg \& Norrgard, 1999), although these concerns are distal and do not interfere with their future personal pathways (Poole \& Cooney, 1987).

Longitudinal studies support the idea that adolescents establish their personal goals for the future by comparison with the developmental tasks they must realize at a certain age and with the transitions in the roles they play over time. To achieve these goals, adolescents then have to build their plans given the institutional opportunities they are faced with in different life domains (e.g., school), in the relationships with peers and in society in general. It is expected that developmental patterns and beliefs about the appropriate behaviours for certain age provide a basis for evaluating the success along different developmental pathways, which in turn is expected to influence self-concept (Nurmi, 1993). A study conducted by Nurmi, Poole and Kalakoski (1994) confirms that this is the case, revealing that the goals teenagers set for the future are related with future occupation, with education and family.

The content analysis of the future orientation of adolescents living in environments that contain high levels of risk, such as young people living on the street, show that these young people, when asked about their wishes and fears for the future, give different answers than those given by the population of adolescents that were used in most studies conducted in different countries (Raffaelli \& Koller, 2005). Although issues of education, work and family also emerge among adolescents living on the street, they are not, however, predominant themes. Many people express vague desires that relate to personal success and the possession of material stuff. Raffaelli and Koller (2005) hypothesize that the confusion of wishes for the future of these young people may result from the perception they have that their goals will be hardly achieved. "Indeed, when young youth were asked to predict what they would be doing at age 18, few generated predictions that matched their hopes, suggesting a mismatch between hopes and expectations" (p. 258).

Wishing to understand the relationships between future orientation and behaviour, Trommsdorff and Lamm (1980) conducted an investigation which examined the relationship between delinquency, institutionalization and future orientation. The results showed that delinquents, especially those institutionalized in prisons, structure their future in a less differentiated, less extensive and more internal way than non-delinquents. However, delinquents structure their fears concerning their personal development with a greater extent than non-delinquents. Future orientation varies according to length of institutionalization, in different life domains. Institutionalized delinquents anticipate future negative events they consider it will occur shortly after the moment of their release.

Despite some authors have taken a conceptual evolution of future time perspective to future orientation, in this paper those two concepts were not understood as synonymous. 
In accordance with the distinction made by Nuttin and Lens (1985) between temporal orientation and time perspective, in the empirical study presented here is made an analysis of temporal orientation of institutionalized adolescents and also of their future time perspective.

\section{Adolescents in institutional care}

One of the protection measures of children and young people at risk with wider expression in Portugal is institutional care. In Children and Youth Residential Homes, official designation for the institutions that take care of underage in need of protection for extended time periods, there are many children and adolescents who are waiting for a possible return to the family. Existing or not the possibility of this return, the waiting time is usually so long that leaving the institution often happens only with the autonomy of the youngster, who once reached the institution as a child, lived there, and grew till the age limit for staying in the Institution. Given this reality, a reasonably high number of children cross their entire adolescence and prepare for adulthood in institutional care.

Although in an institutional context, young people living there need to realize a set of tasks typical of this developmental phase. The construction of their identity is one of them, which demands the adolescents to orient themselves to the future and explore possible ways to integrate society in a productive way. Adolescence is a period of self-discovery, during which people independently begin to try different roles, rehearse them, transport them to a future that they begin to imagine and for which they begin to make plans and choices. During this moratorium period, adolescents gain a new insight into their life and the experiences they have been living, and they should integrate in this path the future they are beginning to sketch. Thus, by the time of late adolescence or early adulthood, they start to build their life story, personal and subjective interpretation of their history, which will give them a sense of unity to their life and their self. Therefore, their identity will be a result of the internalization of their life story (McAdams, 2001).

An inevitable future event for institutionalized adolescents is their departure from the protection system, which becomes effective with their autonomy. The moment when these youths definitely leave the foster care condition, whether it is familial (Geenen \& Powers, 2007; McCoy, McMillen \& Spitznagel, 2008; Avery \& Freundlich, 2009) or institutional (Dixon \& Stein, 2003; Nickerson et al, 2007; Freundlich, Avery \& Padgett, 2007; Raymond \& Heseltine, 2008), has raised the particular attention of researchers.

Studies that analysed the transition of youths from institutions to the community show that they often change house, they have conflicts with whomever they live with, they experience great work instability, and they have low income (Jones, 2008). Also, they show high levels of school disruption and abandonment, they are victims of exclusion, and they experience vagrancy, victimization from their peers and the loss of friendship and contact with former caregivers (Dixon \& Stein, 2003). Youths who are just about to leave the institution have emphasized the need to be trained in many domains so they can have some success once on the exterior. Although there are some who show a will to leave, many don't feel prepared to live on their own, with autonomy (Freundlich, Avery \& Padgett, 2007).

Every Child and Youth Residential Home that has a teenager under care is inevitably involved in his moratorium; and the longer the time of institutionalization, the bigger 
this involvement is. When, in fact, the care measure is indefinitely prolonged, the life project of these teens is, almost with no other choice, the autonomy. So, the institution needs to help them make real this project, trying to include on them, the personal life projects of the adolescents. At a national level and within child protection, efforts have been made to provide the institutions, in quantity and knowledge, with teams able to find valid alternatives to institutionalization and, when this is not possible, help teens to make a good transition from institution to the exterior on the condition of being independent and autonomous.

The concept of life project encloses an evident time dimension, the future. Defining life projects for the children or adolescents therefore implies planning their future, making a constant mental exercise of anticipation regarding the preparation of those children or adolescents so they can assume on their own the management of their future lives and the establishment of conditions that promote in them a proactive attitude and behaviour towards that time. In adolescence, it is also expected that the adolescents do this type of exercise, through the discovery of their new characteristics, the development of new competences, and the exploration of alternatives that help them make their choices for the future (Nurmi, 2001).

It was within this theoretical framework that this research was thought and the following research questions were formulated: 1) Are the institutionalized adolescents more oriented towards the past than towards the future? 2) What projects do the adolescents make for their future lives?

\section{Method}

\section{Participants}

Following the logic of theoretical sampling, the sample of this research is composed by 17 adolescents ( 9 girls and 8 boys) living in Infant and Juvenile Residential Homes, to whom was applied the measure of residential care under the Law of Protection of Children and Adolescents at Risk. Their age ranged from 15 to 18 years old $(M=16,7 ; S D=0,920)$ and their nationality was mostly Portuguese (only three were from African countries with Portuguese official language). Of the total sample, eight were enrolled in regular education, other eight were attending technical-professionalizing education and one had only finished the first full cycle of basic education. The length of the institutionalization ranged between 5 (minimum required) and 16 years $(\mathrm{M}=9 ; \mathrm{SD}=3,56)$.

\section{Instruments}

The adolescents were interviewed according to a semi-structured guide specifically built to the interview. On the second part of the guide the questions were oriented to explore the future dimension of the adolescents' time perspective. These questions were designed taking into account the literature review on future time perspective and seek to assess various dimensions of this construct, such as content, extent, degree of realism and density. It also sought to explore how the adolescent perceives the involvement and support of the institution in achieving their life projects. 
Temporal Orientation Scale (Holman, 1996; Portuguese version: Nobre Lima, 2008). The original scale consists of 28 items organized into 3 sub-scales representing the orientation to the past, to the present and to the future, that should be classified according to a 5-point Likert scale ranging from "Not at all true" (1) and "Very true" (5). In order to evaluate the temporal orientation of adolescents who are institutionalized, the original version was duly translated and adapted into Portuguese to be used in this study. The factorial structure of the original scale was empirically confirmed, being applied to 245 adolescents, $50.6 \%$ of whom were female, aged 12 to 18 years old. The mean age was 15.21 years $(\mathrm{SD}=1.66)$. This sample has revealed a median value (Kaiser, 1974) of 0.68 of adequacy in the Kaiser-Meyer-Olkin measure and a statistically significant result in the Bartlett test of sphericity $\left(\chi^{2}(378)=1196.40, \mathrm{p}<0.0005\right)$. The result of the ACP (rotation by Varimax method with Kaiser normalization) revealed the existence of three factors, which proved to be interpretable and which items are mostly grouped as in the original scale. Regarding the internal consistency of each of these factors, the values of Cronbach's alpha coefficients obtained are $0.67,0.72$ and 0.66 , respectively for the factors present, past and future.

\section{Procedures}

Once composed the sample, data collection from each adolescent occurred in the Institution they lived. An interview was held, which begun by filling out the Temporal Orientation Scale.

\section{Results}

\section{Temporal orientation}

To study the temporal orientation of the subjects from the sample it was established as hypotheses that institutionalized adolescents are more oriented towards the past than the present or the future time. For the whole sample, the analysis of the statistical means obtained by the group of adolescents in the three factors Present $(\mathrm{M}=3.01 ; \mathrm{SD}=0.77)$, Past $(\mathrm{M}=3.40 ; \mathrm{SD}=0.62)$ and Future $(\mathrm{M}=3.24 ; \mathrm{SD}=0.74)$, does not confirm the established hypothesis. A qualitative analysis of these statistical means shows a greater orientation of the adolescents towards the past and the future than to the present. However, these statistical means are around the same value, causing little significant differences between them that cannot quickly deploy a time to which adolescents are more oriented. The statistical comparison of these statistical means shows that between the present and the past the difference is not statistically significant $(Z=1.667, p=0.096)$, the same happening between the present and future $(Z=0.504, p=0.614)$, and the past and future $(Z=0.262$, $\mathrm{p}=0.794)$. Despite the individual differences that can be found in the temporal orientation of the adolescents which suggest a more obvious orientation to one of the temporal zones, the statistical analysis of the results representing the entire sample did not corroborate the qualitative analysis carried out, showing that adolescents valuate with equal intensity the past, the present and the future. 


\section{Future time perspective}

When asked about their projects for the future, some adolescents were reluctant to speak of times to come. Their answers were evasive and made up of contradictions, as if refusing to think about the future ("I-Do you usually think about your future, or do you ever think about your future? L - Not much. I-No? Why? (...) L - I don't like to think.”).

The reluctance of thinking about the future, which translated into some resistance to elaborate on the subject in the interview, was accompanied by some reservations about making plans for the future. Thinking little about the future, not making plans before, living at the rhythm imposed by daily life, seems to involve less insecurity and a smaller possibility of being surprised by something unpleasant. Despite all this, the interviewer's insistence on the subject undid this initial resistance and led the adolescents to elaborate about their projects for the future. Together with the projects, the adolescents also spoke about their fears, their involvement in fulfilling their projects and the involvement of the Institution.

Next, we present the results obtained in the scope of the future time perspective, considering all the projects exhibited by the adolescents. The value that appears in parenthesis concerns the number of adolescents, among the 17 of the sample, which referred that specific project for the future. The same procedure will be used for the remaining projects referred in this section.

\section{Projects}

Having a job (10). This project represents the assurance of the livelihood of the adolescents after the stay at the Institution, from which they must mandatorily emancipate, becoming autonomous. Therefore, it is important that this job could be "decent", "stable", and "well established".

Having a house (8). Like having a job, "having a house" where to live is a very realistic and concrete project that the adolescents expect to achieve, because it is also synonymous for capability of survival and protection.

Leaving the Institution (5). Although this is a sure event in the future of the adolescents, which will happen at their 18th birthday, or 21 st if they request it, some adolescents stated their will to live outside the Institution's context, clearly establishing their exit as a goal to achieve ("In the future I'd like to not be in the Institution, but at the same I'd like to be well, right?”)

Carrying on with studies (11). Globally, the most immediate projects of the adolescents are connected with carrying on their studies. Five of the adolescents wish to stay in school until the 12th grade, completing the training courses they are already attending which will give them equivalence for this school grade ("But now I'm taking one of table waiter and then, if everything goes well with this course, maybe I'll stay in this one. If not, if I'm not very motivated with this course, I might take the one for pastrycook"), or, when choosing this path, after completing the minimum mandatory education. The remaining six adolescents wish to attain higher levels of education ("To study nursing."). This is the type of project that adolescents thought they would begin between eighteen and twenty years of age, and accomplish around twenty-five. 
Occupation (10). From the ten adolescents who referred the occupation they wish they'd have, half of them had already mentioned that they intended to carry on studying. Except for two of them, curiously, the occupations stated were not a logical consequence of the courses they wanted to take ("be and actress" and "professional football player"). Of the remaining five adolescents, some would like to have two careers, such as "being a firewoman" and "working in health care", or being a "flight attendant" and a "model", or being simply a "software engineer", "footballer", and "doctor" or, as an alternative, a "nurse". The adolescents wished to start performing some of these professions, such as footballer, model or firewoman, at an earlier age, around 20. As for the other occupations, which implied a bigger investment in training, the starting age was later, beginning around 24 .

Hobbies (3). Ideally, these would be hobbies that, however, would also have the potential of being an alternative to the idealized profession, should that not come true ("Music and writing also, because I think that maybe, certainly, I will keep writing, I will keep having my ideas on paper but, I don't know, maybe carry on with music and writing"). This reinvestment would be made at around 30 years of age, a time when the adolescent imagined having a more stable life in professional terms.

Family (13). Most adolescents formulated plans for the future that involved a family, whether it was a new family they wished to start, or doing something that involved their original family. Some of these adolescents even showed both desires. While some of them expressed the will to share their lives with someone ("That I have someone who likes me, a girl'), whether marrying or not, others projected "having a family" that also included children for whom they try to assure a life at the side of their parents, as opposed to the life the adolescents had themselves. Regarding the original family, six adolescents expressed the desire to be more close to their kin, in particular parents and siblings ("I imagine a good life, with my brothers, my mother").

Providing socialsupport (3). Some adolescents showed having concerns of a social nature and included in their projects the development of activities of support to underprivileged social groups ("help children who lived in the street, deprived children and the elderly who need it the most").

Having their own business (3). Some adolescents also showed the desire to establish themselves professionally on their own, developing their own business, for instance, "creating a company" or "having a restaurant". They projected the accomplishment of this dream for when they would be in their 30's.

Living in another country (3). For two of them, leaving the country meant a greater proximity with their families ("My uncle wants that, when I finish school, I go live with him in France, that he would be there and he would help me with what I need"), whilst for the other adolescent leaving abroad was a project with a more exploratory motivation. This would be a project to accomplish before they became 30 years old.

Traveling (2). Traveling seemed to be synonymous for discovery and knowing new places or a way to accumulate a certain type of knowledge to implement in a particular business ("cooking").

Other projects (6). One important wish was the happiness they aimed at in their future lives - "I want to be happy!" or "to be healthy". 
Fears

In what regards themselves, one of the fears expressed more often by the adolescents, concerns life outside the Institution and the capability of living on their own. For six adolescents, leaving the Institution, knowing that they would take on the responsibility for their livelihood, many times not having someone who could be a source of support, was frightening, mainly when they realized other youths who, like themselves also had lived in Childhood and Youth Homes, faced many difficulties and had a life well below what they had imagined ("Not being able to, not being able to do this transition well, from the Institution to the outside."). The prospect of not finding a job that assures them some support and the minimum conditions to live properly, was synonymous for a destroyed future ("Because I think about not knowing if one day... not having a job one day and living in the street.").

The need for livelihood was a vital concern for the adolescents, which could, in some cases, prevent them from attaining certain goals, such as to carry on studying ("I'm afraid that... maybe the biggest one of them is not getting (...) the profession I want to have").

Other adolescents feared for themselves, for their fragility, they were afraid of making the mistake of "not taking the opportunities that people give me" and, because of that, "not having a life" or doing something that would prevent them from reaching their goals and accomplishing their projects. Some adolescents were also afraid of "being alone", "not having a good marriage", "having some serious disease" or "dying".

They also feared "that something happens to my family". They were afraid they would stop seeing, or even losing, their bonding figures "losing my mother and my grandmother and also my father") and they were afraid of not being able to assure the care or their siblings, in the absence of the parents.

\section{Actions leading to the accomplishment of projects}

"Studying" was the action that six of the adolescents most did to assure that they would reach their goals. Studying with commitment, always trying to give the best ("I study every day, like (...) always perfecting, like, I don't know, giving my best"), although some do it with sacrifice. For other five adolescents, reaching their goals arose from actions they considered to depend upon their commitment ("I - Look, what do you try to do for your projects to come true? $L$ - I work for it. I - And how do you work for it? $L$ - [silence]"), their determination ("And having determination, I think so too"), and their effort ("I have to work hard at school"). They also considered that it would be important to "be someone", "have the head in place", not involving themselves in risky behaviours that could turn them away from their goals ("I - What do you try to do for these wishes to come true? $L$ - Not taking the wrong road, studying. I think that's all') and believing in themselves and in what they wished for themselves ("First of all, when we want something, I think that I don't know if I'll achieve it, but I think that we have to have faith in ourselves, I have to have faith in ourselves and in what we are going to do").

Although they identify these attitudes as potential ways of accomplishing their projects, they did not refer any actions they performed that could translate those attitudes, showing difficulties in instrumentalizing their ideas. In fact, all these five adolescents seem to display a behaviour that does not agree with their ideas about how they can accomplish their goals. Some don't plan actions, simply because they avoid thinking about their future or because they recognize their inertia and their low investment in studying ("I - You say you want to 
take the course to become a pastrycook, want to have an occupation, you want children, want to live with someone. What do you try to do in your daily life to make sure that these things will happen? N-I don't know... I hardly think.").

Only one adolescent was able to operationalize her commitment and her effort, presenting concrete actions directly related with some of her projects for the future.

\section{Support from the Home to accomplish projects}

The adolescents seem to recognize in the Institutions a very concrete concern with their transition and adaptation to the outside world. They identified, in this way, several actions taken with the common goal of developing self-competences that would allow them to manage their daily lives with autonomy: "they teach how to cook", "doing laundry and those things. Cleaning the house"; "they teach us to set the table, to eat, doing the dishes too, doing the cleaning and all that". There was also a concern of teaching them to look for certain services, such as health care ("they took us to the doctor and they would go with us and now they stopped doing that so much. Sometimes we go alone, I don't know, which helps us a lot'), or search for financial support from social security that could be a reinforcement to the adolescent's livelihood ("Right now, [the Technician] is, as she knows that I want to leave, she is worried and trying to find a way for me to have some support from social security for when I leave. Some help. She is thinking of my future").

Another line of action that the adolescents recognized in the Technician's work was related with the definition of their school paths and the choice of a profession. Five adolescents referred that the technicians and teachers often questioned them about their preferences and personal choices, thus trying to help them plan their future based on their wishes and finding possible alternatives "The people who deal more with the transition, they are constantly worrying and asking what I..., if I already decided what I want to do in the future, what I want to do.").

Five adolescents in the sample did not recognize any help from the Institution, or they considered that this help was scarce. They did not identify any actions taken by the technicians aimed at the benefit of their future. Within this group of adolescents, two considered that the help they had from the technicians was scarce or none due to the little time they spent together at the Institution ("I - And they help you to think about the future? $P$-Sometimes. When you get here you hardly have any time to talk to the Doctors. You get here, there's almost no one here. And when, when you catch the Doctors here, after five minutes they're already leaving! You hardly have any time to talk.").

\section{Feelings regarding the future}

The feeling that was mostly expressed to describe what the future awakened in the adolescents in the sample was "fear". Fear mainly of "not being able" to achieve what they wished for their future and that this failure would lead to difficulties in their livelihoods, which would translate to a life of poverty, unprotected and adverse. The impossibility of predicting the future was a reason for "anguish" and "concern" for one adolescent, while another one felt "sadness" when he thought that in the future he would not have the company of friends he had made in the Institution. However, three adolescents expressed 
opposite feelings: "anxiety" for the closeness of the future, "happiness" because future represented the possibility of doing the things that gave her most pleasure in her own way and finally a driving force that gave her a proactive attitude.

\section{Discussion}

The risk characteristics borne by the lives of the adolescent's in the sample - the abuse in the past and the institutionalization in the present - raised suspicions that they would be more focused in adverse, perhaps traumatic, experiences of the past and the present and less directed towards the future. The scientific literature tends to confirm this hypothesis with studies that relate, for instance, trauma (Klein \& Janoff-Bulman, 1996; Holman \& Silver, 1998) and depression (Eisenck, Payne \& Santos, 2006; Habermas et al, 2007) with the orientation towards the past, including in adolescents (Kuyken, W.; Howell, R. \& Dalgleish, T., 2006). Nevertheless, the interindividual differences that the qualitative analysis of the data can highlight seem to cancel each other out when the sample is analysed, as a whole, with statistical procedures. In fact, the results of the statistical analysis points to a homogeneity in the attention given by the adolescents to the past, present, and future times, which seem to infirm the hypothesis of there being a greater valuation of the past, mainly in contrast with the future.

A limitation of this study for the purpose of a quantitative analysis regards the size of the sample. This is a small sample, which requires the use of non-parametric statistical tests that have a smaller discriminating power. The validation of these results would demand an evaluation of the time orientation in a larger group of institutionalized adolescent, which would allow applying parametric tests, more sensitive to data variations.

The perspective the adolescents have of their future mirrors a lot of what is their general attitude towards that time that has yet to be lived. Although the results have shown that the attitude the adolescents manifest regarding their future is not the same for all of them, on the whole, fear is essentially what shines through.

Speaking about the future, thinking about the future, and consequently, making long term plans is an exercise that the adolescents only do with reservations (hence all the initial reluctance in the interview), an effect of the feelings and fears that are awakened by it. This fear of thinking about their future is motivated by the uncertainty of being capable of transitioning well from the Institution to the outside world. Here, success means assuring their livelihood with autonomy, i.e. having a job that provides them conditions to live with dignity and, preferably, a job that reflects their professional dreams.

The issue of being capable of having a livelihood in the post-institutional period plays a central role in the perspective of the future of the institutionalized adolescents. This capability of having a livelihood is central not only because it is vital for any individual to think of its own survival, but because the need to work to live can prevent them from accomplishing the future they wish. In other words, when the adolescents leave the Institution they must work in order to assure their livelihood, which could mean they can be confronted with the need to quit studying and, therefore, not being able to achieve goals that depend on a more complete school path in the future. Additionally, when looking for a job with fewer skills, the possibilities that arise will certainly be less capable of providing better conditions of living. 
Although the less favourable scenarios that the adolescents can imagine may become real in the future, they still dare to wish to achieve more ambitious projects. And when they dare to do it, they can, in a certain measure, identify some of those projects. Thus, the attitude of the adolescents towards the future oscillates between the wish for a posterity that brings them safety, good living conditions, and happiness, and a very real fear of not being able to create the conditions for the future to be, in fact, promising. This fear is strengthened by the awareness that, once out of the Institution, they will depend mainly on themselves and that they may lack a support they will no longer have.

When they give themselves the opportunity to have a perspective of their futures, the adolescents can place their life projects in a time frame. These projects are not many, nor varied. They mainly concern staying in school, in vocational schools or in universities, conquering a profession they wish to have in the job they find, both mainly the job itself, to which they add a place to live and a family, with a partner, husband or wife, or even children.

The future time perspective of these adolescents is not very dense, and reaches at most to 40 years of age. Before their 20th birthday they wish to finish their education, find a job, and be settled in a home. The job comes up sooner for the adolescents that decide to pursue vocational training. These are the ones that first wish to start a family, starting at the age of 25 . The others place this kind of project closer to the age of 30 , with children being born in the following 10 years.

After hearing and analysing the adolescents' projects, a certain idealization of their future can be perceived. The job and the home were projects that were stated with much certainty and affirmation, clearly translating the notion that these are projects that they need to accomplish in order to subsist. Regarding the pursuit of school and the occupation, the discourse was vaguer, sometimes a little conditional and revealed very little commitment from the adolescents to accomplish it. In fact, in the adolescents' future time perspective there are no projects that are means to achieve larger projects and the strategies they identify as being necessary to achieve them are only knowledge they do not apply, because they recognize their own inertia. This happens with the simple act of studying, which is, obviously, an essential strategy for progress in school.

The adolescents' perspective of the future does not present thus any structure and, therefore, finishing a university degree and having a certain occupation appears in the adolescents' discourse as idealized projects that they wished to accomplish, but that, simultaneously, they seem to predict they will not be able to reach. Also the family they wish to have appears idealized in their perspective of the future. Regarding this topic, the adolescents' discourse reflects the absence of protection and affection in their lives, patent in the wish to have children and give them a family that is a reference of affection and safety, as they wish they'd had but didn't.

Like the family they wish to start, the adolescents' family of origin is also part of the objects included in their perspective of the future. Their wishes show closeness to the family, harmonious relationships between its elements, with the adolescents themselves playing the part of caretakers of their parents and mainly their siblings. The fears expressed by the adolescents strengthen their need to compensate, in the future, for a life marked by being away from the family. They are afraid of losing, hopelessly, the most significant people they are in contact with in the present.

The future projects for the adolescents are spread along a timeline, without connection between them and scheduled only according to what they imagine is the natural or adequate 
time for accomplishing them, characterizing a perspective of the future with little structure and more imagined than active or motivational.

The perspective of future time of the adolescents in the sample is dominated by their need to ensure an autonomous livelihood and by the presence of the family in their lives. However, there are other goals that populate the vision of the future of these adolescents in a less tangible way, of which professional wishes are an example. These are wishes that do not have a truly thrusting role in the behaviour of these youths, who show difficulty in committing themselves. More than inertia, the attitude they demonstrate reveals a state of dormancy, a torpor that paralyses them and prevents them from acting. It seems that the strength of their fears and dreads overwhelms the strength of consciousness and wishes, preventing these wishes from losing their idealized features and from becoming real projects capable of motivating them to commit more in their accomplishment.

Regarding the value of expectations and aspirations of the adolescents and the supposed role they have on their behaviour, as if assuming in this process of influence the value of self-fulfilling prophecies, Stephen Morgan (2006) contests a supposed causal relationship between these variables. As an alternative, he presents arguments for a relationship that is mediated by the significant people for the adolescent and by the educational institutions, acknowledging in these mediators an important role in the process of reaching educational and professional goals of the adolescents. Morgan supports part of his argumentation in the theses of Pierre Bordieu (1973 in Morgan, 2006), which considered that the structures of society offer unequal opportunities, determining the aspirations of the individual because they establish up to which point these may be satisfied. "And, as such, aspirations and expectations have no autonomous explanatory power, as they are nothing other than alternative indicators of attainment" (p. 1530).

Taking these theses as reference, one can achieve some understanding about the attitude towards the future of the adolescents in the sample, since the family, a very significant reference structure for them, had a weak role in creating conditions for organizing the adolescent's future before institutionalization, and even that role stops after the institutionalization. Once they are living under the care of a Childhood and Youth Home, it becomes evident that this institution needs to organize itself as a way to lessen and compensate the weaknesses that children carry over to this new context, thus becoming a facilitator in the achievement of the adolescents' future projects.

Despite the disadvantage that the Institution has, because it can never become an alternative to a healthy family context, where there is caring and affection, it must try to compensate for these weaknesses in the adolescents by providing them with capabilities that help them make their future viable. And it can do so also by appealing to the participation of other social structures with competences in matters of childhood and youth, which can contribute to reduce the disadvantages with which these adolescents reach the Institution.

Regarding the perception that the adolescents have of the support provided to them by the Institution for the preparation of their future and the accomplishment of their projects, the results leave no doubt that they acknowledge the effort of the Institutions in providing them very practical and concrete experiences with the purpose of enabling them to manage their daily lives and to solve the problems of an autonomous life outside the Institution.

The adolescents also perceive the act of studying as a strategy that is very valued by the Institution, acknowledging in the support teachers an important instrumental value to help them advance in school. They also acknowledge the care of these teachers in helping 
them choose a school path in accordance with their vocations and preferences. In spite of this acknowledgement, the perception that some adolescents have of the mismatch of the technical team and the adolescents should not be underestimated, as neither should the opinion of one adolescent in particular that manifested not having felt any help from the Institution, above in the discovery of his vocations. This mismatch concerns the little time that adolescents and technical team spend together at the Institutions. When the adolescents arrive at the Institution from their school activities, the elements of the technical team are at the end of their work schedule.

Based on the perception that adolescents have of the help they receive from the Home in order to organize their future, it can be seen that Institutions try to prepare the adolescents for a life project that includes autonomy, providing them with practical capabilities for managing their daily lives and for the relationship with the social Institutions that they will have to resort to more often, also promoting the acquisition of school and professional skills, preferably in accordance with their interests and wishes. Here, we have two future projects that must cross paths. One is the project that the Institution must find for the children and adolescents and which has the scope of the protection measures presented by the law as an alternative, and the other is the project that the adolescent himself creates for his future life and which is much broader and encompassing than the previous.

When it is necessary to define a life project for the adolescents, which also includes their interests, the Institution needs to enable them for this team work. And this enablement does not concern only making choices according to their vocations, interests, and wishes. It concerns, above all, the discovery of these vocations and interests, the promotion of personal skills for exploration, self-construction, and decision, which give the adolescents conditions to discover their motivations and skills, so that they can then accomplish, in their future, less idealized choices, that will thrust them towards the persistence to achieve them.

This work does not seem much different from what is done for any adolescent, whether institutionalized or not. An adolescent that lives with the family usually relies on its help to develop the skills mentioned. The data from this research show a relation between attachment and the motivational strategies of adolescents, suggesting that students with a secure attachment have better motivational strategies than those with an insecure attachment (Soares, Lemos \& Almeida, 2005).

However, a fear of thinking about the future was identified in institutionalized adolescents and, therefore, they need help to achieve it. This is because their future exists only as a thought, and if it is not possible to think about it, it is not possible to plan it. If planning the future in a realistic way is painful for these adolescents, they need help to do it. Otherwise, it will be difficult or even impossible for them to become the adult they imagine, an adult with strong psychological characteristics, as shown in the results found.

\section{FUTURE RESEARCH}

Further research on time orientation of adolescents in institutional care is needed. A qualitative and more individual analysis of the results suggested that there are adolescent who are in fact more directed to the past instead of the future, but there are others who are as just as or even more focused on the future than the past. What is the meaning of the differences at the time orientation level between the adolescents in this sample? Is the 
orientation towards the past in fact synonymous for maladaptation and the orientation towards the future coherent with a more adaptive behaviour? Other investigations with larger samples should be carried on in order to clarify this suppositions and to study the relations between temporal orientation and future time perspective in institutionalized adolescents, which may bring more clear data that might help technicians to conceive more adequate strategies to help these individuals developing better life projects.

\section{REFERENCES}

Abreu, M. V. (1999). Tarefa Fechada e Tarefa Aberta. Motivação, Aprendizagem e Acção. Coimbra: Imprensa da Universidade de Coimbra

Avery, R. \& Freundlich, M. (2009). You're all grown up now: termination of foster care support at age 18. Journal of Adolescence, 32, 247-257

Braley, L. \& Freed, N. (1971). Modes of temporal orientation and psychopathology. Journal of Consulting and Clinical Psychology, 36, 33-39

DeVolder, M. (1979). Time orientation: a review. Psychologica Belgica, XIX-1, 61-79

Dixon, J. \& Stein, M. (2003). Leaving Care in Scotland: the Residential Experience. Scottish Journal of Residential Child Care, 2(2), 7-17

Freundlich, M., Avery, R. \& Padgett, (2007). Preparation of youth in congregate care for independent living. Child and Family Social Work, 12, 64-72

Geenen, S. \& Powers, L. (2007). “Tomorrow is another problem”. The experiences of youth in foster care during their transition into adulthood. Children and Youth Services Review, 29, 1085-1101

Habermas, T., Ott, L-M; Schubert, M., Schneider, B. \& Pate; A. (2007). Stuck in the past: negative bias, explanatory style, temporal order and evaluative perspectives in life narratives of clinically depressed individuals. Depression and Anxiety, 0, 1-12

Jones, L. (2008). Adaptation to early adulthood by a sample of youth discharged from a residential education placement. Child Youth Care Forum,37, 241-263

KaIser, H. F. (1974). An index of factorial simplicity. Psychometrika, 39, 31-36

Klein, I. \& Janoff-Bulman, R. (1996). Trauma history and personal narratives: some clues to coping among survivors of child abuse. Child Abuse and Neglect, 20 (1), 45-54

Lamm, H., Schmidt, R. \& Trommsdorff, G. (1976). Sex and social class as determinants of future orientation (time perspective) in adolescents. Journal of Personality and Social Psychology, 34, 317-326

Lens, W. (2006). Future Time Perspective: a psychological approach. In. Z. Uchnast (Ed.). Psychology of Time. Lublin: Wydawnictwo KUL, 51-64

Lomranz, J., Shmotkin, D., Zechovoy, A. \& Rosenberg, E. (1985). Time orientation in nazi concentration camp survivors: forty years after. American Journal of Orthopsychiatry, 55, 230236

Malmberg, L-E \& Norrgard, S. (1999). Adolescents' ideas of normative life span development and personal future goals. Journal of Adolescence, 22, 33-47

McAdams, D. (2001). The Psychology of Life Stories. Review of General Psychology, 5 (2), 100-122

McCoy, H., McMillen, J. \& Spitznagel, E. (2008). Older youth leaving the foster care system: Who, what, when, where, and why? Children and Youth Services Review, 30, 735-745

Morgan, S. (2006). Expectations and aspirations. In George Ritzer (Ed.). The Blackwell Encyclopedia of Sociology

Nickerson, A., Colby, S., Brooks, J., Rickert, J. \& Salamone, F. (2007). Transitioning Youth 
from Residential Treatment to the Community: A Preliminary Investigation. Child Youth Care Forum, 36, 73-86

Nurmi, J-E. (1991). How do adolescents see their future? A review of the development of future orientation and planning. Developmental Review, 11, 1-59

Nurmi, J-E. (1993). Adolescent development in an age-graded context: the role of personal beliefs, goals, and strategies in the tackling of developmental tasks and standards. International Journal of Behavioral Development, 16(2), 169-189

Nurmi, J-E. (2001) . Navigating through adolescence: introduction. In. J-E. Nurmi (Ed.) Navigating through Adolescence. European Perspectives. New York \& London: Routledge Falmer, 3-17

Nurmi, J-E., Poole, M. \& Kalakoski, V. (1994). Age differences in adolescent future-oriented goals, concerns and related temporal extension in different socio-cultural contexts. Journal of Youth and Adolescence, 23(4), 471-487

Nurmi, J-E., Poole, M. \& Segriner, R. (1995). Tracks and transition. A comparison of adolescent future-oriented goals, explorations and commitments in Australia, Israel and Finland. International Journal of Psychology, 30, 3555-375

Nuttin, J. \& Lens, W. (1985). Future time perspective and motivation. Theory and Research Method. Leuven: Leuven University Press

Poole, M. \& Cooney, G. (1987). Orientation to the future: a comparison of adolescents in Australia and Singapore. Journal of Youth and Adolescence, 16(2), 129-151

Quinton, D., Pickles, A., Maughan, B. \& Rutter, M. (1993). Partners, peers and pathways: assortive pairing and continuities and discontinuities in conduct disorder. Developmental Psychology, 5, 763-783

Raffaelli, M. \& Koller, S. (2005). Future expectations of Brasilian street youth. Journal of Adolescence, 28, 249-262

Rappaport, H., Enrich, K. \& Wilson, A. (1985). Relation between ego identity and temporal perspective. Journal of Personality and Social Psychology, 48, 1609-1620

Raymond, I. \& Heseltine, K. (2008). What Does it Mean to be an Adult? Perceptions of Young Men in Residential Care. Child Youth Care Forum, 37, 197-208

SEginer, R. (1998). Adolescents' perception of relationships with older siblings in the context of other close relationships. Journal of Research on Adolescence, 8, 287-308

Soares, I., Lemos, M. \& Almeida, C. (2005). Attachment and Motivational Strategies in Adolescence: exploring links. Adolescence, 40(157), 129-154

Trommsdorf, G. (1986). Future time orientation and its relevance for development as action. In. R. K. Silbereisen, K. Eyferth \& G. Rudinger (Eds.). Development as action in context: Problem behavior and normal youth development. Berlin, Germany: Springer, 121-136

Trommsdorf, G. \& LAmm, H. (1975). An analysis of future orientation and some of its social determinants. In. J. T. Fraser \& N. Lawrence (Eds.). The study of time II. New York: SpringerVerlag, 343-361

Trommsdorfa, G. \& Lamm, H. (1980). Future orientation of institutionalized and noninstitutionalized delinquents and nondelinquents. European Journal of Social Psychology, 10, 247-278

Wyman, P., Cowen, E., Work, W., Raoof, B., Gribble, P., Parker, G. \& Wannon, M. (1992). Interviews with children who experienced major life stress. Family and Child Attributes that predict resilient outcomes. Journal of the American Academy of Child and Adolescent Psychiatry, 31, 904-910

Zimbardo, P. \& Boyd, J. (1999). Putting time in perspective: a valid, reliable individual-differences metric. Journal of Personality and Social Psychology, 77(6), 1271-1288 